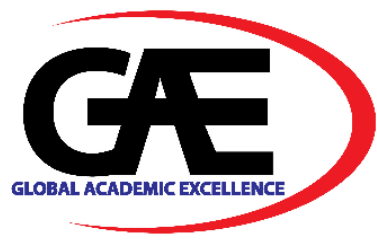

\title{
FARMERS DEPENDENCY IN THE POTATO SUPPLY CHAIN IN BATUR, CENTRAL JAVA, INDONESIA
}

\author{
B.Junianto Wibowo ${ }^{1 *}$, Veronica Kusdiartini' ${ }^{2}$, Ika Rahutami ${ }^{3}$, Dyah Titisari Anugraheni ${ }^{4}$, Ign \\ Supriyanto ${ }^{5}$
}

1 Department of Management, Faculty of Economics and Business, Soegijapranata Catholic University, Indonesia Email: yunianto@unika.ac.id

2 Department of Management, Faculty of Economics and Business, Soegijapranata Catholic University, Indonesia Email: vero@unika.ac.id

3 Department of Management, Faculty of Economics and Business, Soegijapranata Catholic University, Indonesia Email:ika@unika.ac.id

4 Department of Management, Faculty of Economics and Business, Soegijapranata Catholic University, Indonesia Email: dyah@unika.ac.id

5 Department of Management, Faculty of Economics and Business, Soegijapranata Catholic University, Indonesia Email: igsupri@unika.ac.id

* Corresponding Author

\section{Article Info:}

\section{Article history:}

Received date: 21.03 .2021

Revised date: 30.04 .2021

Accepted date: 20.05.2021

Published date: 01.06.2021

\section{To cite this document:}

Wibowo, B. J., Kusdiartini, V., Rahutami, I., Anugraheni, D. T., \& Supriyanto, I (2021). Farmers Dependency in The Potato Supply Chain in Batur, Central Jaya, Indonesia. International Journal of Supply Chain, Operation Management and Logistics, 2 (4), 0113.

\section{Abstract:}

One of the leading potato-producing areas of Indonesia is the Batur subdistrict in Banjarnegara, Central Java. The Batur sub-district has potential for potato cultivation and business. However, most farmers in this area still follow the wholesaler's price. According to farmers, they must obey the policies of wholesalers after they get credit from wholesalers through collectors. Moreover, farmers can also not know the potato market with certainty due to the limited mastery of market information, especially prices and added value to various actors in the potato supply chain. This study aims to: (i) describe how the potatoes supply chain in Batur, Banjarnegara; furthermore, the comparison of potato prices and value-added by distribution channel, (ii) discuss and analyze the causes of differences in potato market prices and value-added in distribution channels, (iii) recommend the appropriate potato distribution strategy. The data required include secondary and primary data. Secondary data were obtained from the Central Bureau of Statistics, Department of Agriculture. Meanwhile, primary data was obtained through a questionnaire from 20 potato farmers and traders from Wonoyoso, Sumberejo, Batur, and Grogol villages. Interviews were conducted with six potato farmer groups. The results showed that potato farmers were weak compared to other potato supply chain actors such as wholesalers, collectors, wholesale market traders in other provinces, retailers, MSMEs, factories, and exporters. The dependence of farmers on local wholesalers is quite substantial because wholesalers control potatoes' marketing network from upstream to 
DOI: $10.35631 /$ IJSCOL.24001

This work is licensed under $\underline{\mathrm{CC} B Y} 4.0$

(1) downstream. The study recommendations are restructuring and improving cooperation performance and providing business loans with lower interest rates and fast processing. The Agro Cooperative will shorten the potato distribution channels and provides potato farmers with important information such as market information and business conditions.

\section{Keywords:}

Supply Chain, Potato Price, Value Added

\section{Introduction}

Potatoes, or commonly known as Solanum Tuberasum, are priority horticultural and food crops commodities to be developed in Indonesia. Potatoes are also a source of carbohydrates, widely consumed by many of Indonesia's people in addition to rice. According to Andriyanto, Setiawan, \& Riana (2013), Indonesia's potato consumption has increased extraordinarily from year to year. Increasing potato's demand needs better and continuous potato production. Figure 1 is the potato's production data.

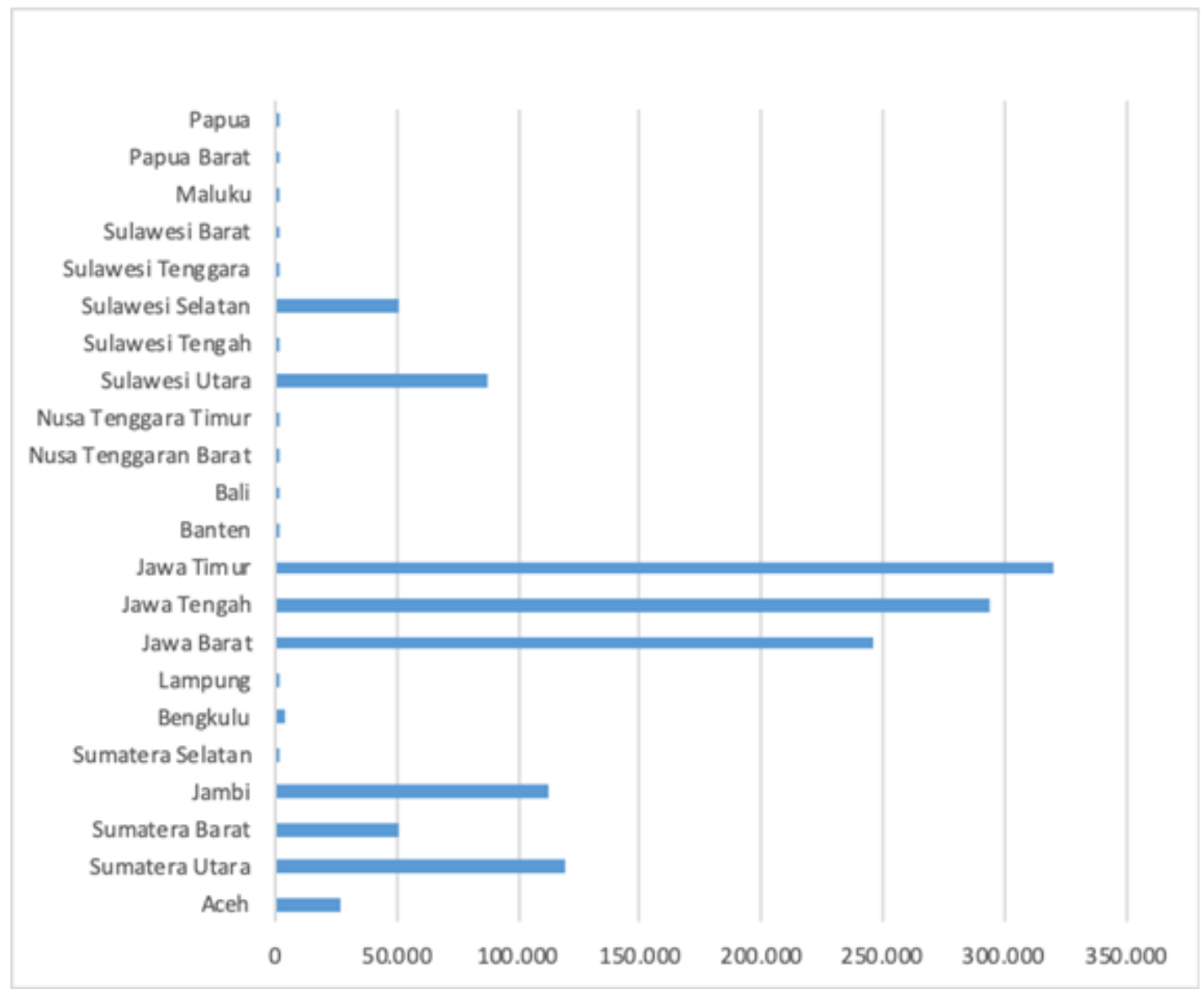

Figure 1. Potato Production by Province, 2019

Source: Agriculture Office, 2019 


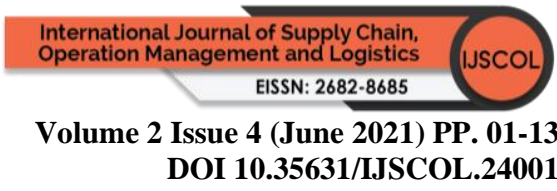

Of those 22 provinces, five of them are the largest potato producers. They are East Java, Central Java, West Java, North Sumatra, and Jambi provinces. Batur, Banjarnegara, Central Java is the region that produces the best quality potatoes. Batur area has an altitude of 1663 to 2093 meters above sea level, making it appropriate for potato crops. Besides, the land in the district of Batur includes fertile "andosol" soils with the right sunlight intensity and sufficient rainfall. This favorable condition is supported by a potato seed development center's presence to make superior potato seeds. Potatoes from this area are widely used to produce fast food, potato chips, and various other snack foods besides raw vegetables (Sodhiq, 2020).

The total area of potato plants for the Batur sub-district is around 430 acres and spreads in Wonoyoso, Sumberejo, Batur, and Grogol (Central Bureau of Statistics of Banjarnegara, 2019). Batur and Wonoyoso villages have the largest potato crop areas, 228 acres, and 100 acres (table 1). The potatoes produced in these two villages were 1,644.65 tons for Batur village and 689.30 tons for Wonoyoso village, with a total production of 2,795 tons from all villages. Apart from being caused by area size, the number of plant populations also affects the amount of potato production produced (Mastuti, 2014). The sizeable potato production is related to the Batur sub-district, designated as the center for potato production (Mastuti, 2017).

Table 1. Planted Area, Potato Production and Productivity in 2019

\begin{tabular}{lcrrr}
\hline $\begin{array}{c}\text { Sub- } \\
\text { District }\end{array}$ & $\begin{array}{c}\text { Land } \\
\text { Ownership } \\
\text { Data } \\
\text { (Acres) }\end{array}$ & $\begin{array}{c}\text { Population } \\
\text { (Plant) }\end{array}$ & $\begin{array}{c}\text { Production } \\
\text { (Ton) }\end{array}$ & $\begin{array}{c}\text { Productivity } \\
\text { (Ton/Acres) }\end{array}$ \\
\hline Wonoyoso & 100 & 954.000 & 689,30 & 6,89 \\
Sumberejo & 49 & 468.000 & 379,50 & 7,75 \\
Batur & 228 & 2.178 .000 & $1.644,65$ & 7,21 \\
Grogol & 53 & 504.000 & 81,69 & 1,54 \\
\hline Total & 430 & 4.104 .000 & $2.795,00$ & 6,50 \\
\hline
\end{tabular}

Source: Central Bureau of Statistics of Banjarnegara, 2019

From the level of productivity, it turns out that Sumberejo Village has the highest level of potato productivity, in the amount of 7.75 tonnes per acre. This condition happens because of smooth irrigation, better sunshine, more fertile agricultural land, and infrequent pest attacks. On the other hand, the lowest level of potato productivity was found in Grogol, at 1.54 tonnes per acre. This condition happened because the village of Grogol was in a basin so that the falling fog was trapped, and it was not easy to move. This condition results in late blight, which impacts decreasing the quality of the potato plant so that the potato yield loss reaches 50\% (Rukmana, 2012). Also, the water used for irrigating potato plants is not smooth, and there are plant pests. 


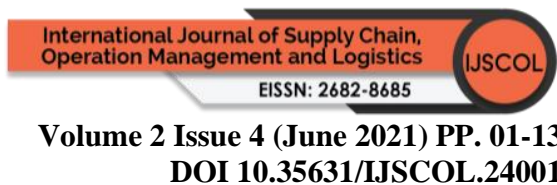

The potatoes produced include Granola, Tejo M.Z., Atlantic, and Agria (Sub Directorate of Horticultural Plants, 2017). (table 2)

Table 2. The Kind of Potato, Potato Form and Utilization of Potato in Batur SubDistrict

\begin{tabular}{|c|c|c|}
\hline $\begin{array}{c}\text { The Kind of Potato in } \\
\text { Batur Sub - District }\end{array}$ & Potato Form & Utilization \\
\hline $\begin{array}{c}\text { Granola } \\
\text { Tejo M.Z. } \\
\text { Atlantic } \\
\text { Agria }\end{array}$ & $\begin{array}{l}\text { Potatoes are oval, and flesh is yellow } \\
\text { Oval-shaped and whitish-yellow flesh } \\
\text { Round and pale whitish flesh } \\
\text { ample tuber-shaped and dark yellow } \\
\text { flesh }\end{array}$ & $\begin{array}{l}\text { For vegetables } \\
\text { For vegetables } \\
\text { For the food industry } \\
\text { For the food industry }\end{array}$ \\
\hline
\end{tabular}

Source: Sub Directorate of Horticultural Plants, 2017

From table 2, it can be seen that there are four kinds of potatoes in Batur Sub-District, which each has a different form and utilization. Those different kinds of potatoes are used for households and industries. For household, potatoes required are vegetable potatoes such as Granola and Tejo M.Z. For the food industry, potatoes such as Atlantic and Agira are required as raw for processing to be chips, pasta, donut, frozen potatoes, etc.

In supporting the advancement of their business, potato farmers form farmer groups. The farmer groups' tasks include conducting regular meetings to compile a potato cultivation program, holding outreach in cooperation with the agricultural agency and business groups, and planting and maintaining potato crops until harvest. Apart from working through farmer groups, promoting potato business is also done through agro cooperatives, whose members consist of potato farmers. The cooperative tasks include receiving savings and providing loans to farmers even though the interest is relatively high. The cooperative also provides potato production facilities such as fertilizer, medicines, agricultural equipment and accommodates potato chips produced by potato farmers.

In marketing potatoes, wholesalers set the price of potatoes from farmers. This condition happens because it has something to do with the bonded bond system, an agreement made between large traders and farmers. In the agreement, through collector traders, wholesalers provide credit to farmers to finance the cultivation of potato crops up to harvest. These farmers also use this credit to pay for their daily needs. When the harvesting season comes, the farmers should hand over their potatoes to the wholesaler.

Moreover, farmers cannot control the potato market due to the lack of market information controlled. On the other hand, farmers also do not know the price, added value, and profitability of various actors in the potato supply chain. This phenomenon is under the research results by Miftah, Arti, \& Rivanda (2019), which states that traders have set the price of potatoes received by farmers. Thus, farmers cannot enjoy a profitable potato price when the potatoes are distributed to retailers. The same thing is evidenced by Kaido \& Fuyuki (2020) 's research results, which show that the distribution of prices, added value, and profits from the distribution of pineapples from various parties involved are not the same. This condition is detrimental to farmers as producers of agricultural products.

Besides being marketed to various regions, potatoes are also sold by collectors to micro, small and medium enterprises (MSMEs) or Home Industry, especially around the Batur. The 


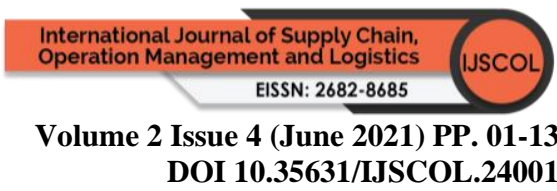

potatoes are processed into chips, donuts, potato cream soup, and potato wedges. The problem faced by potato farmers is that farmers have not been able to determine the price of potatoes correctly. Most of them also do not know the market price of potatoes sold by traders in other cities, either in one province or another, and sold by exporters. On the other hand, the price of potato-based processed products currently circulating in the market is not specific. The added value obtained from all potato business actors other than farmers is relatively high. Based on this phenomenon, this study aims to (i) describe how the potato supply chain is in the Batur, Banjarnegara. Furthermore, this study also explains the comparison of potato prices and value-added by distribution channel; (ii) discusses and analyzes the causes of differences in potato market prices and value-added distribution channels; (iii) recommends the appropriate potato distribution strategy.

\section{Literature review}

\section{Supply Chain}

In the agricultural sector, agricultural commodities' distribution starts from farmers, distributors, retailers to consumers (Heizer \& Render, 2014). These activities represent a coordinated chain, starting from farmers to consumers. This phenomenon is in line with Cooper et al. in Somashekhar, Raju, \& Patil (2014), which explains that the distribution of a product, including agricultural commodities, starts with production by farmers, then is followed by distribution and marketing activities so that agricultural commodities reach consumers. It is also per Widisatriani et al. (2015), who find out that the supply chain of cayenne pepper seeds economically conducted by Idea Foundation as wholesalers, collectors, and retailers. Meanwhile, Anugraheni et al. (2018) explain that the model of coffee cultivation in Magelang regency has increased the supply chain of coffee. That is proof that the amount of coffee harvest in Magelang regency is stable from year to year.

In contrast, Kusdiartini et al. (2017) find out that supply chain management of chile from farmers to consumers is very long. That is proven by finding that there is low price chile at farmer's level but the high price at consumer's level. The low price has made the farmer poor. One of the factors is that institutions associated with chili farms do not yet execute their tasks successfully.

\section{Value Added}

Unlike in developed countries, in developing countries, the marketing of agricultural commodities is more complex, and the costs involved are pretty significant. This fact is in line with Somashekhar, Raju, \& Patil (2014) research results, which show that agricultural marketing in India. India's agricultural marketing is characterized by fragmented supply chains, significant losses during post-harvest, high transaction costs, many market intermediaries, lack of awareness, and other socioeconomic factors. The results of research conducted by Kaido \& Fuyuki (2020) show that the distribution of pineapples from the Muaro Jambi district to various regions causes different prices, added value, and benefits to the various parties involved. This condition is related to the condition of the pineapples sale. Large, unripe pineapples are sold to wholesalers, while ripe pineapples of low quality are sold to intermediaries. Miftah, Arti, \& Rivanda (2019) stated that long-lasting vegetables in the city of Bogor include potatoes imported from remote locations. 
Meanwhile, Hamidah et al. (2015) explain that processing cassava to be cassava chips form high value-added. It occurs because of a long-expired date. Moreover, almost all people like to consume it.

\section{The Price of Agricultural Commodity}

Meanwhile, the traders set the price of potatoes received by farmers. This situation shows that if farmers are very weak in determining potatoes' price, they obey and stick to the trader's potatoes. The consequence is low profitability because farmers have to cover all costs incurred, including the price of seeds, maintenance costs, pesticides, labor costs, and transport costs. Meanwhile, Rosmawati (2015) explained that in Ujan Mas village, Dempo Utara sub-district, Pagar Alam city, Bengkulu, there had been a decline in potato production. This condition is caused by many farmers who have switched to business coffee, which is considered more profitable. Farmers considered switching to the coffee business because the capital they spent was relatively lower than that of the potato business. From the agricultural input, the price of potato seeds is relatively high. The quantity and quality of potato seeds are not correct, and the limited labor causes a decrease in potato production.

\section{Methodology}

The research was conducted in the Batur sub-district, Banjarnegara district, Central Java. The reason for choosing the location was since this area is a relatively sizeable potato-producing area. In addition, the quality of the potatoes produced is the best potato among potatoes produced from other regions in Indonesia. This study uses secondary data and primary data. Secondary data were obtained from the Central Bureau of Statistics, Agricultural Service.

Meanwhile, primary data were obtained through questionnaires and interviews. The population in this study included farmers, traders, and potato farmer groups located in Wonoyoso, Sumberejo, Batur, and Grogol villages, Batur sub-district, Banjarnegara district. The sample uses the purposive sampling method. The questionnaire in this study includes three supply chain flows: the flow of goods, the flow of information, and the flow of money distributed to 20 potato farmers and traders in the village. Meanwhile, interviews were conducted with six potato farmer groups. The criteria for farmers as a sample are farmers whose profession is permanent as potato farmers whose business is stable, the length of the business has been more than 15 years, the potato business is the mainstay of household economic livelihood with 12 farmers selected.

Furthermore, eight traders were selected as samples, with the criteria that the potato trading business had become a permanent profession, had broad insight into new markets at the national level, and provided capital to farmers. Meanwhile, the selection of 6 potato farmer groups was based on the criteria that the six people in this group are superior farmers who have the largest land area between 2 ha to 4 ha. They had earlier information on potato prices and potato marketing policies. In addition, they already have better farm management governance. Analysis of the supply chain of potatoes is carried out to determine the selling price and value-added from the potato supply chain actors involved in it. The added value is obtained from the difference between the selling price and the purchase price of each actor. Furthermore, based on the selling price and added value, a qualitative analysis is carried out to determine the various things that cause a difference in price and added value. 


\section{Discussion of Findings}

\section{Potato Supply Chain in Batur}

Data description and analysis, starting with various parties involved in potato marketing, consisting of potato farmers, collectors, wholesalers, home industry or MSMEs, factories, exporters, wholesale market traders in other provinces, and retailers. There are five distribution systems in potato marketing in the Batur; they are:

1. Distribution Channels I: Potato farmers sell the harvested potatoes to collector traders, then collectors sell them to home industries (MSMEs).

2. Distribution Channels II: Potato farmers sell the harvested potatoes to collectors, then the potato collectors sell them to wholesalers, then the wholesalers sell the potatoes to exporters.

3. Distribution Channels III: Potato farmers sell the harvested potatoes to collectors, then the potato collectors sell them to wholesalers, then the potato wholesalers sell them to traders in wholesale markets in other provinces, and then resell them to retailers.

4. Distribution Channels IV: Potato farmers sell their harvested potatoes to wholesalers from other cities in Central Java, and then by wholesalers, the potatoes are sold to retailers.

5. Distribution Channels V: Potato farmers sell potatoes to collectors through farmer groups, then the potato collectors sell them to factories.

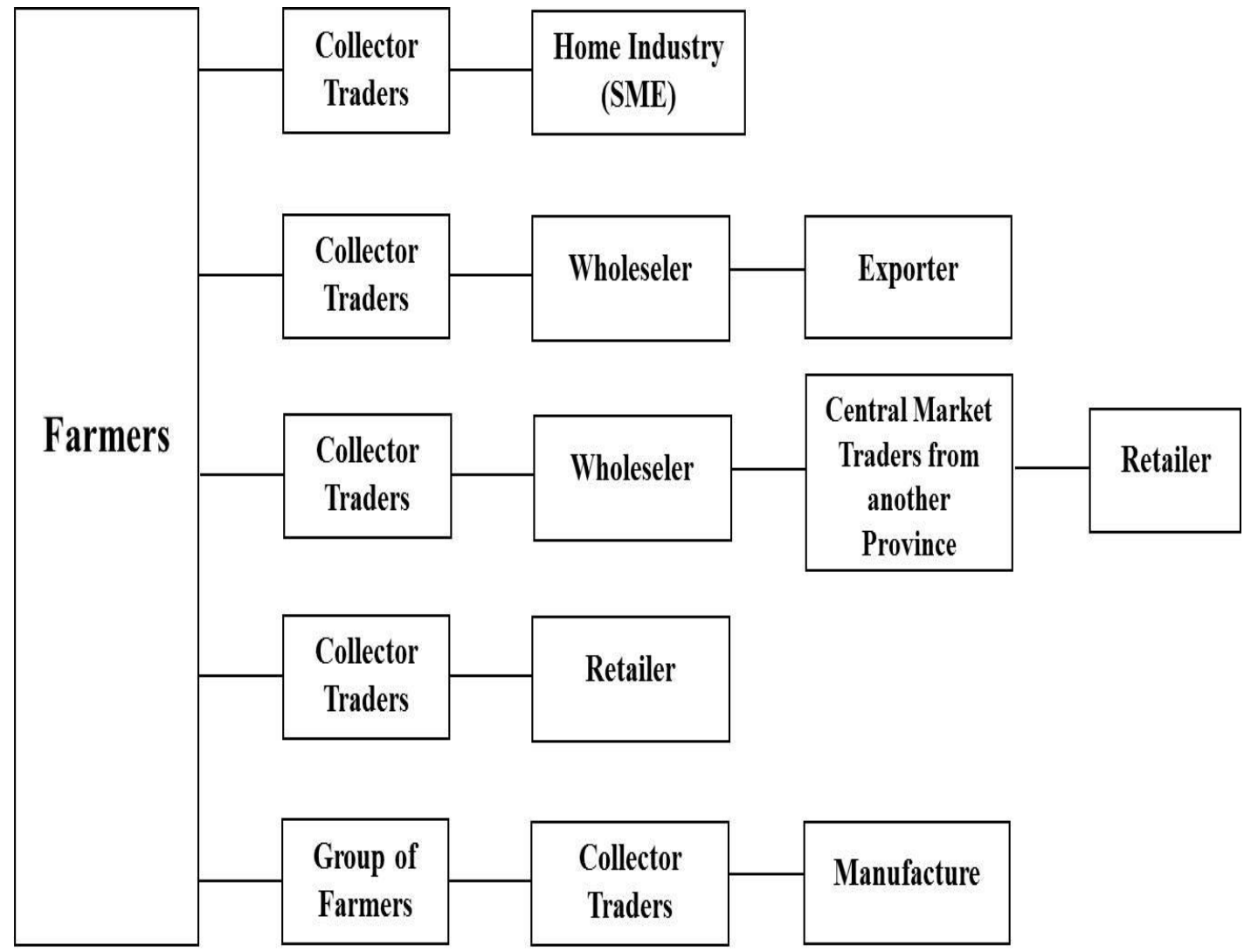

Figure 2. Distribution System of Potatoes in Batur Sub-District

Source: Interview with Potato Traders 2019 


\section{Comparison of Potato Prices Based on Distribution Channels}

Price comparisons based on the distribution channels of parties in the potato supply chain vary, as shown in figure 3:

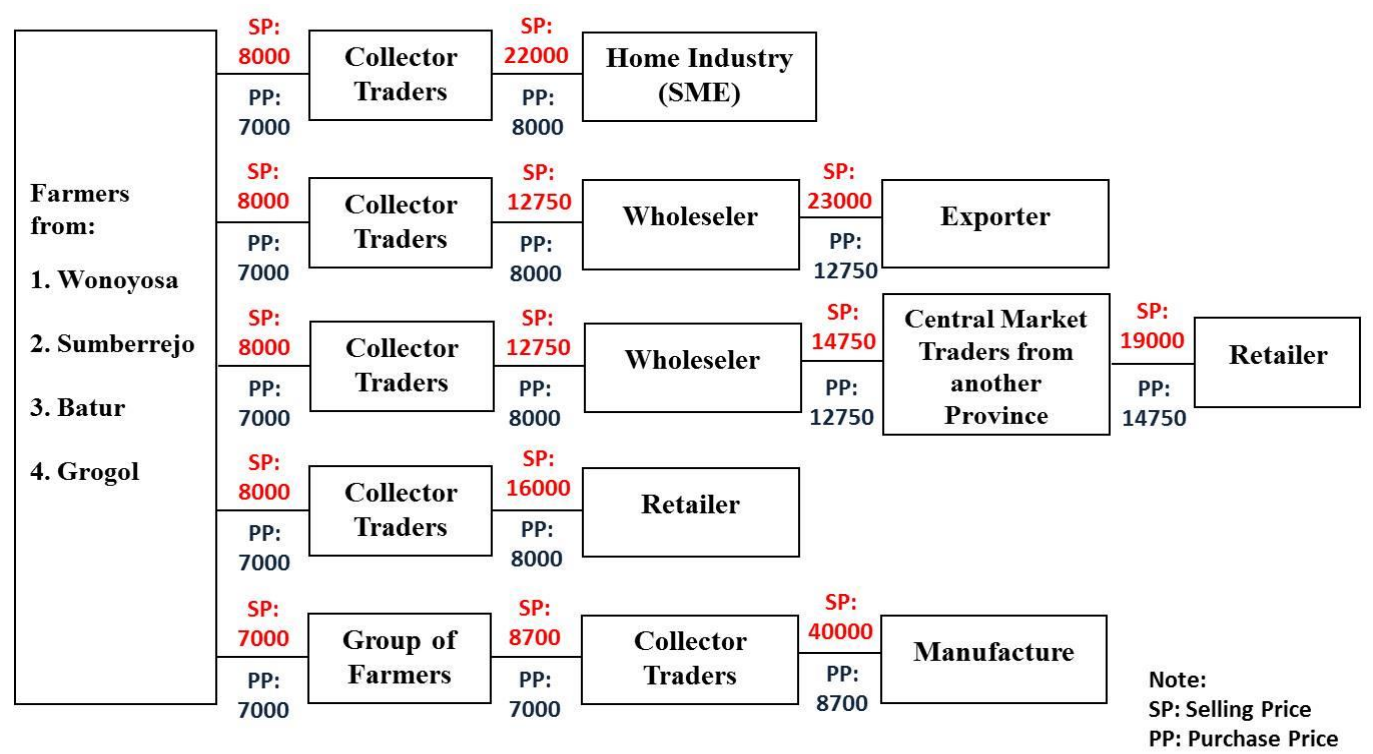

Figure 3. Price Comparisons Based on The Distribution Channels

Source: Interview with Potato Traders 2019

Figure 3 shows that potatoes from farmers from Wonoyoso Village, Sumberejo Village, Batur Village, and Grogol Village are an average of IDR 7,000 per kg. The following route is collecting traders. Collector traders sell potatoes for IDR 8,000, and large traders in other cities sell for a difference of IDR 500 more expensive. The following route shows that wholesalers and MSMEs (Home Industry) buy potatoes from collectors at IDR 8,000. Local wholesalers sell potatoes at IDR 12,750, while MSMEs can sell at IDR 22,000. This situation is also due to the processing costs of raw potatoes into semi-finished potatoes ready for consumption. Prices at the traders and exporters level tend to be higher. Main Market Traders from Other Provinces and Potato Exporters obtain potatoes by buying potatoes from Local Wholesalers with a price range of IDR 12,750 . Whole market traders from other provinces sell for IDR 14,750, while exporters can sell up to IDR 23,000. The same thing happened to retail traders in other cities in one province to buy potatoes from wholesalers from other cities at IDR 8,500 and sell them for IDR 16,000 to consumers. The same is the case with retail traders in other provinces. They buy potatoes from wholesale market traders from other provinces for IDR 14,750 and sell them for IDR 19,000. The highest sales were obtained at the factory level, where the product was processed potatoes, the raw material of potatoes purchased from collectors at a partnership price of IDR 8,700 and sold for IDR 40,000. 


\section{Value Added Comparison by Distribution Channels.}

The added value among actors in potato distribution is not the same. This value can be seen from the comparison of added value based on distribution channels, as in figure 4.

\begin{tabular}{l|l|l}
\multicolumn{1}{c}{ Parties to the Potato Supply Chain } & $\begin{array}{c}\text { Group of } \\
\text { Potatoes }\end{array}$ & $\begin{array}{l}\text { Value Added } \\
\text { Collector Traders }\end{array}$ \\
Local Wholesaler & $\begin{array}{l}\text { Consumption } \\
\text { Consumption }\end{array}$ & $12,50 \%$ \\
Wholesaler from another city & Consumption & $37,25 \%$ \\
Central Market Traders from another Province & Consumption & $17,65 \%$ \\
Home Industry & Consumption & $13,56 \%$ \\
Exporter & Consumption & $63,64 \%$ \\
Retailer from another province & Consumption & $44,57 \%$ \\
Retailer from another city in the same province & Consumption & $22,37 \%$ \\
Manufacture & Consumption & $50,00 \%$ \\
\hline
\end{tabular}

Figure 4. Value Added Comparison by Distribution Channels

Source: Questionnaire, 2019

Figure 4 shows that the most considerable added value of potatoes is the added value obtained by the factory, which is equal to $78.25 \%$. The home industry is $63.64 \%$, retail traders in one province are $50.00 \%$, exporters are $44.57 \%$, and local wholesalers $37.25 \%$. The added value at the factory and MSME levels shows that the processed food products made from potatoes have a high value. This condition is inseparable from the increasing public demand for processed foods made from potatoes in various big cities, small cities, and villages. At the level of retail traders in one province, the added value of potatoes is also considerable, indicating that public demand, especially among homemakers in various cities in Central Java, is quite large. Public awareness of the importance of eating vegetables is getting higher amid the spread of various fast foods. Most of the potatoes are imported from potato farmers through wholesalers in each city.

Meanwhile, the exporter level is added value is mainly in line with the increasing demand for potatoes from various countries. Initially, the export destination countries for potatoes were only a few countries in Asia. Now the export has increased to various countries such as Malaysia, South Korea, Papua New Guinea, Hong Kong, Singapore, Taiwan, Thailand, Australia, Austria, Bangladesh, Cameroon, China, East Timor, Japan, India, Maldives, New Zealand, and Qatar. At the local wholesaler level, the significant value-added shows that the demand for potatoes from the community, especially from wholesale market traders, originates from Central Java, West Java, Lampung, West Kalimantan, and DKI Jakarta. Likewise, exporters also tend to increase. So far, wholesalers have good relations with all the potato supply chain actors, including wholesale market traders in other provinces and with exporters.

\section{Analysis of the Causes of Difference in Price and Value Added in Distribution Channels.}

Based on the description above, it is clear that there are differences in prices between distribution channels. At the farmer level, the selling price of potatoes is the price that the 


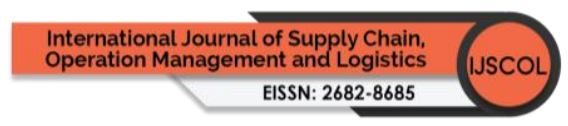

Volume 2 Issue 4 (June 2021) PP. 01-13

DOI 10.35631/IJSCOL.24001

wholesaler has set. In Indonesia, the wholesaler is also known as "pengijon" (traders who buy before the harvest of potatoes). Through collector traders, Wholesalers have a stake in helping farmers in financing related to land rental costs, land management, procurement of seeds, procurement of fertilizers, medicines for pest and plant disease management. Assistance to finance farmers' businesses is in the form of loans, the repayment of which is calculated from the sale of potatoes. The difference between farmers' purchase price and the selling price is extreme and challenging terrain, the road to land infrastructure, and inadequate and remote cultivation. Some still need transport laborers, with high costs, and the mode of transportation used is only capable of carrying capacity. A little, so it must be shaded several times. Meanwhile, the price difference between the purchase price and the selling price is due to the cost of harvesting, washing costs to clean potatoes from the ground, location conditions, road access, distance to the market, and transportation modes. Higher prices at wholesalers are due to transportation costs, cost of lowering potatoes, cost of sorting and grading (tuber classification), based on super quality class: > $400 \mathrm{~g}$ (consumption bulbs), quality A: > 250g - $400 \mathrm{~g}$ (consumption bulbs), quality B: > $100 \mathrm{~g}-200 \mathrm{~g}$ (consumption bulbs). For exporters, apart from these costs, there are still other costs that must be incurred, such as quarantine costs, container costs, cold storage costs, insurance costs, certification fees, export-import taxes, and unexpected costs. This condition results in higher prices for potatoes sold to other countries.

The price difference between MSMEs and factories is because potatoes have become a processed product. From the interview results, the MSME distribution channel, even though the processing is manual and the packaging is still simple, the costs incurred are significant. The costs of using supporting materials, labor costs, storage costs, transportation are relatively high. So MSMEs process the potatoes as a home Industry will sell potatoes at a high price. The price difference is striking at the factory because the potatoes sold to consumers have been processed into processed products that are ready to eat by processing using machines and are all hygienic and have been packaged. This processing requires many costs, such as storage costs, supporting materials, labor costs for production, transport costs, and marketing costs. Also, changes in people's lifestyles that increasingly prefer potato-based food products such as fast food, pasta, and other food types have driven increased demand for these potato-based foods. From the description of added value, there is also a difference. The added value is enormous at the factory and home industry level because they can implement high production efficiency. This condition shows the use of a center fuse, which is an oil filter that causes the product to dry out quickly. This equipment has prompted the company to produce various variants of potato-based products that are very salable in the market.

On the other hand, the purchase price of potatoes from collectors is meager compared to the value of processed potatoes sold in the market. The transportation cost expenditure is also relatively low, especially in the procurement of potatoes. This condition is because most of the potatoes are delivered directly by collectors. Meanwhile, at the retail level in one province, the added value is due mainly to increasing demand and exceeds the supply. This phenomenon is related to changes in a healthy lifestyle so that many people use potatoes as a substitute for rice. Also, some retailers already have regular customers who obey and always follow the retailer's price (market of place).

Another thing that determines the amount of added value at the retail level is market sentiment, which is volatile and tends to rise. The gains in added value are also quite significant at the exporter level due to the fluctuating and increasing trend of the foreign 


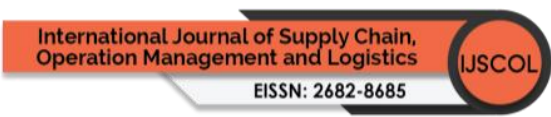

Volume 2 Issue 4 (June 2021) PP. 01-13

DOI 10.35631/IJSCOL.24001

exchange rate, increasing the selling price of potatoes in rupiah. On the other hand, government policies that reduce export duties and eliminate Letter of Intense fees related to processing product invoices and export quotas have boosted exports, including potato exports. The price of potatoes and the added value of selling potatoes outside of potato farmers seem very profitable, but potato farmers do not yet enjoy it. This opportunity cannot be exploited because potato farmers still rely on wholesalers and collectors for potatoes' pricing and marketing. The consequence is that there is a risk that must be borne by potato farmers in the potato supply chain. It changes in potato prices that can occur every time. If the potatoes' market price decreases, the wholesaler will ask the potato farmers to hand over their harvested potatoes at a lower price. Potato farmers cannot escape, even though the costs incurred are increasing. This condition is following the results of research conducted by Pujiharto \& Wahyuni (2018), which shows that, in general, vegetable farmers in the Dieng Plateau have not been able to implement a marketing strategy through pricing. Besides, potatoes' shrinking nature encourages farmers to immediately sell them to wholesalers through intermediate traders to earn income quickly. Thus, the potato farmer can use his income for his family's needs, repaying business credit, and financing the next potato business. The respectful attitude of potato farmers was increasingly evident by several large traders' appointment as cooperative managers, which led to a stronger position of the wholesaler in the potato supply chain. The strategy undertaken by the cooperative management is to condition the cooperative so that it does not carry out several activities that can harm local wholesalers.

The Agro cooperative has not carried several activities, namely: (1) They have not accommodated yet and marketed potato yields from potato farmers to various markets. So far, their harvested potatoes are only accommodated in the cooperative, then the cooperative distributed to traders in other cities who have been appointed. (2) They have not yet provided business credit with low-interest rates. Business loans with low interest rates will make all business costs efficient so that the resulting profit will be more significant. (3) They have not yet processed the potatoes into products with high added value. So far, farmers' potatoes are only collected, the rotten ones are removed, then the good ones are cleaned, then distributed. (4) They have not yet provided valuable market information for farmers. The information is given to potato farmers so far is only on some issues, such as production technology, superior seeds, and climate change. Meanwhile, market information that benefits farmers and is strategic is rarely given to potato farmers.

\section{Conclusions and Recommendations}

Based on the analysis and discussion results above, it can be concluded that potato farmers are weak compared to collectors, wholesalers, traders in the primary market in other provinces, retailers, MSMEs, factories, and exporters in the potato supply chain. Potato farmers are very dependent on wholesalers because wholesalers control the potato marketing network from upstream to downstream. The wholesaler's position is in the middle between the farmer and the collecting trader. The wholesaler is in the primary market in other provinces. The exporter and the retailer are also established. Potato farmers always follow various policies made by wholesalers through collector traders to maintain their business continuity. Besides that, potato farmers also depend on collector traders to distribute their harvested potatoes to home industries and factories. Potato farmers are not fully aware that potatoes can be processed into various high value-added food products. So far, agro cooperative services for potato farmers are still not optimal. It is proven that many farmers have not been served directly by the credit union. 


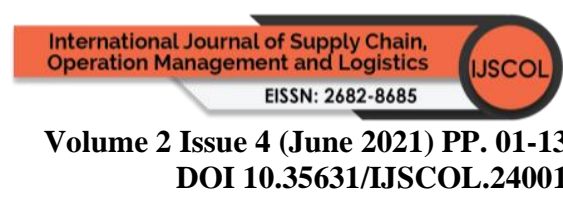

Most of the farmers are served by large traders because, so far, the farmers have objected to meeting the cooperative requirements. Farmers who get capital from large traders are only farmers who have good relations with large traders. Meanwhile, other farmers felt that they received different treatment, especially regarding the procurement of seeds, production facilities, and market opportunities. Based on the conclusions, the recommendation is that agro cooperatives restructure various efforts to improve cooperatives' performance, which have not been evenly served, especially in savings and loan services. A policy of providing business credit with a lower interest rate and fast processing needs to be realized. Farmers can finance their business with efficient business costs.

On the other hand, cooperatives need to form productive business units. These business units include a production unit that processes potatoes from potato farmers into high value-added food products. This marketing unit handles the marketing of potatoes produced by farmers and processed products made from potatoes. The cooperative should shorten the potato distribution channel by accommodating the potatoes produced by potato farmers, sold to retailers, exporters, and wholesalers at wholesale markets in other provinces. However, this should not be deterred from local wholesalers' role because they are also in charge of the Agro cooperative. This situation means that there is a division of territory between potato farmers through cooperatives and large traders. The territory's division is intended to make it easier to find buyers and avoid fighting over buyers who are already customers. Zoning will also facilitate business facilities preparation, obtaining the necessary seeds and market information, counseling, and training. Thus, potato farmers and wholesalers both benefit so that excellent cooperation can be established. Providing critical information to potato farmers through credit unions must be done frequently, especially on the market and business conditions of vegetables, especially potatoes, both at the national and global levels. It is intended that potato farmers can keep up with external changes affecting their business to continue, and potato farmers are not disadvantaged.

\section{References}

Andriyanto, F., Setiawan, B., \& Riana, D. F. (2013). Dampak Impor Kentang Terhadap Pasar Kentang di Indonesia. Jurnal HABITAT, Vol. XXIV, No.1.

Anugraheni, D. T, Kusdiartini, V., \& Supriyanto, I. (2018). Coffee Supply Chain and Marketing Channel Management in Central Java. southeast Asia Journal of Contemporary Business, Economics, and Law, Vol.16, Issue 3 (August) ISSN 2289$15601-8$

Central Bureau of Statistics of Banjarnegara. (2019).

Ganeshkumar, C., Pachayappan, M., \& Madanmohan, G. (2017). Agrifood Supply Chain Management: Literature Review. Intelligent Information Management, Vol. 9, 68-96.

Heizer, Jay \& Render, Barry. (2014). Manajemen Operasi: Manajemen Keberlangsungan dan Rantai Pasokan. Jakarta : Salemba Empat.

Hamidah, M., Hamida, A., Yusra \& Sudrajat, J.(2015). Analisis Nilai Tambah Agroindustri Kripik Ubi di Kota Pontianak, Jurnal Social Economic of Agriculture, Volume 4, Nomer 2, Desember 2015. 60-73

Kaido, Boris \& Fuyuki, Katsuhito. (2020). Supply Chain and Value-Added Distribution of Pineapple Fruit in Muaro Jambi Regency, Jambi Province, Indonesia. International Journal of Research in Economics and Social Sciences, Vol.10 Issue 2, 2249-7382. Retrieved from http://euroasiapub.org

Kementerian Pertanian. (2020). Produksi Kentang Menurut Propinsi Tahun 2015-2019. Retrieved from www.pertanian.go.id 
Kusdiartini, V., Supriyanto, I., Wibowo, B. Y, \& Rahutami, A. I. (2017). Chili Supply Chain And Pricing Management In Sumowono Central Java. International Journal of Business, Economics, and Law, Vol.13, Issue 2 (August), ISSN 2289-1552. 1-10

Mastuti, Sri. (2014). Data Statistik Sayuran Regional Banjarnegara, Kabupaten Banjarnegara: Kantor Disperindakop dan UKM.

Mastuti, Sri. (2017). Banjarnegara Kembangkan Sentra Industri Kentang, Kabupaten Banjarnegara: Kantor Disperindakop dan UKM.

Miftah, H., Arti, Y., \& Rivanda, D. R. (2019). Kinerja Rantai Pasok Produk Sayuran di Kota Bogor. Jurnal Pemikiran Masyarakat Ilmiah Berwawasan Agribisnis, 5 (1), 23-32.

Pujiharto \& Wahyuni, Sri. (2018). Strategi Pemasaran Produk Sayuran Dataran Tinggi Di Wilayah Kecamatan Batur Kabupaten Banjarnegara. Journal AgriTech, Vol.XX, No.2.

Rosmawati, Henny. (2015). Analisa Faktor-Faktor Produksi pada Usaha Tani Kentang di Desa Ujan Mas, Kecamatan Dempo Utara, Kota Pagar Alam. Journal Society Vol. IV, No.1, 59-61.

Rukmana, Rahmat. (2012). Usaha Tani Kentang Sistem Mulsa Plastik. Yogyakarta: Kanisius.

Sodhiq, Arif. (2020). Kentang Dieng Paling Disukai Pelaku Bisnis Restoran. Retrieved from https://sariagri.id

Somashekhar, I. C., Raju, J. K., \& Patil, H. (2014). Agriculture Supply Chain Management: A Scenario in India. Research Journal of Social Science \& Management, Vol. 04, No.7.

Sub Directorate of Horticultural Plants. (2017). Efisiensi Tehnis Usaha Tani Kentang dan Faktor-Faktor yang Mempengaruhi. Banjarnegara: Kementrian Pertanian, Sub Direktorat Tanaman Hortikultura.

Widisatriani, A. G., Widyantara, I. W., \& Angreni, I. G. A. A. L.(2015). Manajemen Rantai Pasok Benih Cabai Rawit (Kasus di Yayasan Idep, Desa Batuan Kaler, Kecamatan Sukawati, Kabupaten Gianjar), E-Jurnal Agribisnis dan Agrowisata, Vol 4.No.4. Oktober 2015. 289-297 